\title{
The Status of Female Garment Workers' Health on STIs/HIV and the Role of Garment Factory Owners in Bangladesh
}

\author{
Shakeel Mahmood, PhD Candidate \\ School of Humanities and Social Science, Faculty of Education and Arts \\ University of Newcastle, Callaghan, Australia
}

URL:http://dx.doi.org/10.19044/esj.2020.v16n23p23

\begin{abstract}
The RMG (ready-made garment) sector is an export-oriented industry in Bangladesh. RMG has given Bangladesh and its women an immense image boost in South Asia and globally. This paper focuses on critically examining the personal understanding of health risk faced by female garment workers (FGWs), particularly their sexually transmitted infections (STIs) and human immunodeficiency virus (HIV) experiences, and what needs to be done by the owners of the garment factories in Bangladesh to improve the health status of their FGWs. A systematic and comprehensive literature search was carried out, which was published between 1995 and 2020. It was revealed by several studies that health is an essential issue for garment employees. Garment factory owners violate the safety and security of the workplace and maintain inhumane working conditions. FGWs have been sexually assaulted by male co-workers as well as factory owners within the workplace. These FGWs, therefore, become susceptible and vulnerable to life-threatening diseases such as HIV and STIs. The literature shows that $43 \%$ garment owners believe that sexual harassment does not influence factories growth and development. To resolve health problems, all the parties such as FGWs, Garment factory owners, Bangladesh Garment Manufacturers and Exporters Association (BGMEA), researchers, and policymakers in Bangladesh have to work together to improve the health of women, especially on STIs and HIV. Above all, FGWs, including male partners and the owners of the factories, should be involved in preventive programmes concerning HIV/STIs and sexual harassment.
\end{abstract}

Keywords: Owners of garment factories, female garment workers, STIs/HIV, sexual harassment 


\section{Introduction}

The modern phase of globalization has shaped an exceptional outlook for women to be considered as vital contributors to the global labour force. This means that the entire global labour force is made up of 1.3 billion women (Kabir, Maple, \& Fatema, 2018). The RMG (ready-made garment) sector is a $100 \%$ export-oriented industry. According to an analysis published in Journal of Business in 1999, the RMG of Bangladesh has given the country and itswomen an immense image boost in South Asia and globally. In 2014, Bangladesh exported 35 kinds of clothing products to 31 countries around the globe (Azad, 2014). According to a 2016 Daily Star report and 2017 Drapers report, Bangladesh could become the world's top exporter of garments in a decade and the European Union's largest clothing supplier as China is gradually moving away from its long-held supremacy over the manufacture of low-end apparel (Daily Star, 2016; Drapers, 2017). However, this contributed to $82 \%$ of Bangladesh's total export earnings, which is valued at over $\$ 34$ billion in 2015 (BGMEA, 2016) and more than 14\% of the GDP (2016-2017) (BGMEA, 2017). It has been contributing to the national economy from the last 3 decades (M. M. Hasan, Parven, Khan, Mahmud, \& Yajuan, 2018). In 2014-2015, Bangladesh exported $61 \%$ of RMG products to European Union (EU) countries and $21 \%$ to the United States of America (USA) (Bhattacharjee, 2018). Therefore, research on the health status of female garment workers' (FGWs) is important to the economy of Bangladesh.

In the framework of Bangladesh, RMG sector has succeeded within the setting of the country's independence in 1971. This was in response to the contemporary globalization practices influencing the economic and political climate (F. E. Ahmed, 2004; Kabeer\&Mahmud, 2004). Many positive social changes have occurred in the lives of Bangladeshi women with the introduction of the RMG industry in Bangladesh (Kabeer\&Mahmud, 2004). Hence, the rise of the RMG sector since independence is a response to combined forces, including globalization, the flow of neo-liberal economic strategy, and the pressure of international donor groups (Kabir et al., 2018). Bangladesh is now the world's leading garment exporters, second only to China. In other words, after China, Bangladesh is the world's second-largest apparel exporter, which is primarily due to its massive population and low labour costs (CHAN CHAO, 2016). The low cost of wages makes the Bangladeshi RMG workforce the cheapest in the world (Morshed, 2007; J. Siddiqui \& Uddin, 2016). Women constitute more than $90 \%$ of the entire labour force of this sector (M. S. Islam, Rakib, \& Adnan, 2016). However, supervisors are mostly male (Campaign, 2012; Kabeer\&Mahmud, 2004). More than $90 \%$ of the FGWs are the migrants from rural areas and a majority of them migrated from landless families (Rita Afsar, 2000; N. J. Chowdhury \& Ullah, 2010). RMG employs 4 million workers (Barua \& Ansary, 2017; 
FWF, 2013) out of a total population of over 150 million (Foundation, 2013); (Campaign, 2012; Kabeer\&Mahmud, 2004). For the majority, it is also their first job (Kabeer \& Mahmud, 2004a). FGWs employed in the RMG contribute $46 \%$ to their family income (SI Khan, 2001). Furthermore, the industry accounts for $70 \%$ of the total female workforce employed in the Bangladesh manufacturing sector (Bhattacharya \& Rahman, 2000).

\section{Availability of Health Services to FGWs in Bangladesh}

The FGWs are unable to buy proper foods, clothes, housing, medical expenditure, over time payment, transportation cost, and education because of low wages, absence of health facilities, lack of industry safety measures, and lack of safe drinking water in the factories (Absar, 2001; Bheda, 2004; Z. A. Bhuiyan, 2012; M. M. Hasan et al., 2018; Hasnain, Akter, Sharafat, \& Mahmuda, 2014; M. S. Islam et al., 2016). Regarding medical allowances from the employer, in one study, it was found that $26 \%$ of the FGWs receive nothing from their employers/owners for medications if they become sick $(\mathrm{N}$. J. Chowdhury \& Ullah, 2010). In every sociological aspect, they receive less attention, particularly in food and health care services. Thus, these low skilled FGWs share the most exploited and unprotected labour force world-wide (F. Ahmed, Hasan, \& Kabir, 1997; T. Siddiqui \& Farah, 2011 ). According to WHO (1948), "Health is a state of complete physical, mental and social wellbeing and not merely the absence of diseases or infirmity". However, FGWs in Bangladesh are unable to manage any of the health conditions as set by the WHO (S. Ahmed \& Raihan, 2014). FGWs also face a restriction on having babies because of fear of losing the job, although having a baby is a human right (Paul-Majumder, 1996).

The government of Bangladesh (GOB) has made an effort to address female health service needs. Under the Health Nutrition and Adolescent Health Program (HNPSP) (1998), the GOB has created the Maternal Nutrition and Adolescent Health Program (MNADH) as a part of reproductive health care under the essential service package. However, there is no explicit program for FGWs. Some non-government organizations (NGOs) are working for these disenfranchised, disadvantaged, and poor group (Khatun et al., 2013).

\section{Poor FGWs Vulnerability and HIV/STIs in Bangladesh}

All workers in garment factories are vulnerable and susceptible to numerous types of illness, disease, and physical injury as a result of working in unsafe and unhygienic conditions (Absar, 2001; Ahamed, 2013; S. Ahmed \& Raihan, 2014; Bhattacharjee, 2018; Paul-Majumder \& Begum, 2000). According to Shaheen Ahmed, many FGWs suffer from numerous illnesses after starting work in the garment factories such as bones, abortion complexity, dermatitis, back pain, eye stain, pruritus, malnutrition, respiratory 
problems, hepatitis (Jaundice), gastric pain, fatigue, fever, abdominal pain, common cold, and helminthiasis (R Afsar, 1998; S. Ahmed \& Raihan, 2014). Since the growth of the garment sector in Bangladesh, easily available cheap labour is the key formula for a prosperous RMG industry. However, the cost saving practice in the RMG industry often affects the health and safety of the FGWs (M. S. Mahmud et al., 2017).

With insufficient or low salaries, short term temporary or seasonal work and due to the gap between salary and living costs, an increasing number of women are reportedly involved in sex work according to surveys (Khosla, 2009). Cultural forces exist that add pressure to such decisions, and the FGWs engage in sex work so that they can increase the amount of money sent to their family members (Kabir et al., 2018). 'Action Aid Bangladesh, a British NGO stated that $20 \%$ of the women they interviewed from the garment factories in Bangladesh were engaged in sex at the workplace (T. Islam, 1998; Kabir et al., 2018). In some cases, women may consent to engage in sex work. Nevertheless, this is usually not the case. Women are also subject to being sexually assaulted by male co-workers as well as factory owners within the workplace (S. Ahmed \& Raihan, 2014; Siddiqi, 2003). As a consequence of sex work, whether voluntary or not, women become susceptible and vulnerable to life-threatening diseases, such as human immunodeficiency virus (HIV) and sexually transmitted infections (STIs), in addition to the health vulnerabilities such as other health complications (illness, physical injury) experienced by FGWs from their employment activities in the garment factories (IFC, 2011; T. Islam, 1998; Kabir et al., 2018). As a result of their employment, FGWs experience illness and become unable to continue working (Kabir, Maple, Usher, \& Islam, 2019). Good health conditions for the FGWs would benefit the garment factory owners and the economy in the long run. In this case, if FGWs do not get ill, then they will be able to continue to work all through the year which would accelerate garment productions (Haque, Begum, \& Fahmida, 2008).

Thus, the aim of the research is to critically examine FGWs personal understandings of health risk, particularly their sexually transmitted infections (STIs) and human immunodeficiency virus (HIV) experiences. It concludes with what can be done by the owners of the garment factories to improve their health status in Bangladesh.

\section{Method}

\section{Identifying Relevant Studies}

A systematic review was carried out which was available in databases of Medline, PubMed, Google Scholar, Ebsco, Embase, Proquest, Scopus, ResearchGate, World Health Organization, and the United Nations. Google Scholar is a non-academic search engine (Haque et al., 2008). However, it was 
included here to capture all available evidence on STIs/HIV on FGWs from Bangladesh, which might have been published in journals not indexed on the included databases. Manual searching was piloted to categorize and review relevant articles in academic database of the library of University of Newcastle, Australia. Articles covered a comprehensive range which included social science, public health ethics, and descriptive reports, including BGMEA annual report and thesis paper.

The keywords used are shown in Table 1 below:

Table 1. Keywords

\begin{tabular}{|l|l|l|}
\hline$\#$ & Nature & Keywords \\
\hline 1 & Nature of the factory & 'owner', 'ready-made', 'readymade', 'RMG', 'BGMEA' \\
\hline 2 & Nature of infection & $\begin{array}{l}\text { 'sexually transmitted disease', 'human immunodeficiency } \\
\text { virus', 'syphilis', 'gonorrhoea', 'chlamydia'; }\end{array}$ \\
\hline 3 & Nature of the exploitation & $\begin{array}{l}\text { 'violence', 'Intimate partner violence'. 'workplace } \\
\text { violence', 'rape', 'sexual violence' }\end{array}$ \\
\hline 4 & Nature of the gender & 'women and health', 'female', \\
\hline 5 & Nature of the work & 'labour', 'labor', \\
\hline 6 & Nature of apparels & 'garment' or 'clothing' or 'fabric' or 'textile', \\
\hline 7 & Country of origin & 'Bangladesh' \\
\hline
\end{tabular}

\section{Study Selection}

The literature search was conducted between October 2017 and July 2020 to identify among FGWs from Bangladesh. Collected articles were reviewed and synthesized for analysis during this period. Overall, 2671 documents were retrieved from the databases of peer reviewed journals and websites from 1995-2020. Online social and public health and STIs and HIV related journals were explored for relevant publications. The review was completed in two stages. Firstly, an extensive search of the existing literatures was conducted, and then the collected literatures in relations of their relevance of women's health, particularly FGWs on STIs and HIV, were screened. 140 documents have been cited in this paper. During the review, development efforts were made to synthesize the relevant resources to increase a comprehensive understanding. A cross sectional prevalence and historical observations and study of STIs and HIV in Bangladesh were included. This study was designed as a mixed method (qualitative and quantitative) descriptive review paper. This critical review tried to contribute to existing literature in the form of new outcomes and critically assess existing results targeted at reducing the risk of HIV/STIs in women. This particularly refers to FGWs in Bangladesh and what should be the role of the owners of the garment factories to improve their health status in Bangladesh. The corresponding author executed a content analysis of all data and summarized it under certain themes, and then compared and contrasted the outcomes as they relates to 
FGWs and their vulnerability and susceptibility to STIs/HIV (Gale, Heath, Cameron, Rashid, \& Redwood, 2013).

Figure 1. Flowchart of the studies selected

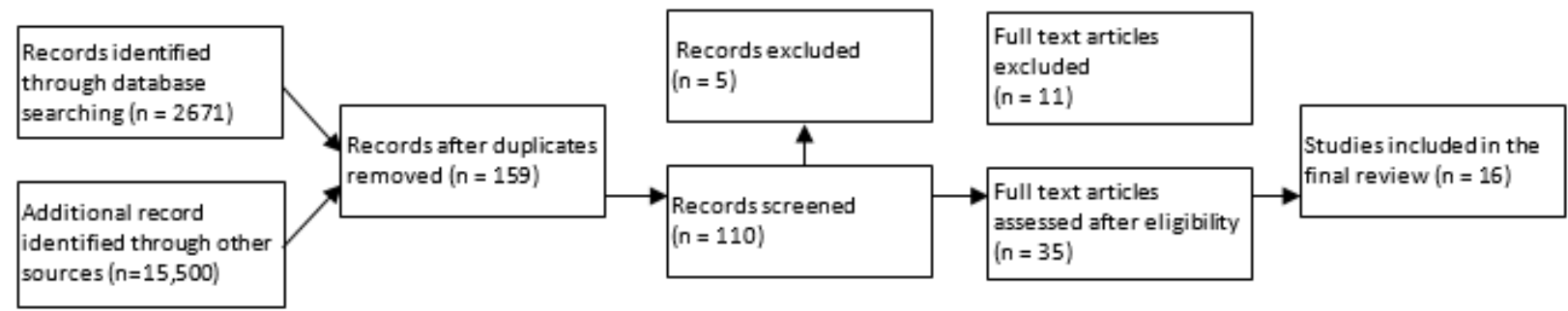

Figure 1 shows the flowchart of the studies selection reported in this systematic review. Searching through databases generated an initial 2671 results from which duplicates were removed and reference list were checked for possible further sources. After duplicates were removed, a review of 159 abstracts to find empirical papers showed 115 full text to review. Also, 5 additional papers were removed because they did not include a sample of garment workers. After reviewing the full text, 11 articles were removed because they only included an occupation health and socio-political consciousness with exclusion criteria. A total of 16 studies that met the search criteria remained in this systematic review.

\section{Charting the Data}

Microsoft Excel was used for the purpose of organization, and the data extracted from the articles were recorded on it. The year, authors of the article, and country where the study was conducted were arranged in spreadsheets.

\section{Collating, Summarizing, and Reporting the Results}

All studies included in this systematic review were descriptive crosssectional studies $(n=16)$ except for one study, which was a prospective study $(\mathrm{n}=1)$. All studies addressed health outcomes among garment and textiles workers, including STIs and HIV and AIDS. Participants included workers who were dedicated to cutting, weaving, sewing, stitching, finishing, dyeing, and ironing.

\section{Geographic Location of the Study Sites}

The geographic location of each study included in this systematic review fits into the criteria to be categorized as a low middle income country, i.e., Bangladesh. 


\section{Eligibility Criteria}

Inclusion Criteria

The corresponding author served as reviewer for the selection of the articles. Corresponding author also screened the titles and abstracts of each article for potentially relevant articles. Articles were included if they met the inclusion criteria for this systematic review. The criteria are as follows:

- $\quad$ Peer-reviewed research published between 1995 and 2020.

- Literature based on secondary data and reports and review articles.

- Article included data on health vulnerability, especially on STIs/HIV vulnerabilities and susceptibilities, labour rights, gender issues, social compliance, awareness about hygienic practices, construction of the factories, economic development, Rana Plaza Disaster, and sociopolitical consciousness and wages.

- Published in English.

- Data collected from Bangladeshi FGWs.

\section{Exclusion Criteria}

- Research articles that focused on cotton industry, silk industry, and other export processing zone (EPZ) were excluded.

\section{Literature Review}

Poor Health and Safety Status of Disenfranchised FGWs

Health is an important issue to promote occupational safety and health and to improve working conditions for FGWs (Campaign, 2012; M. M. Hasan et al., 2018). The FGWs employment opportunity has created some vulnerability because of health susceptibilities, low life standards, mental pressure, unsafe working conditions, etc. Personal, family, and aggregate economic impacts of these garment industry jobs in Bangladesh are vital and there is a need to address the health status of FGWs at the comprehensive policy level. However, the GOB, with its relaxed industrial relations rules and regulations, has been described as being indifferent and lenient to concerns raised about the RMG sector (J. Siddiqui \& Uddin, 2016). This is typified by the slow response of the government in the 2013 garment factory fire that killed many FGWs.

\section{Disadvantaged FGWs and Poor Socio-economic Strata}

All workers in garment factories are vulnerable within the factory and this sector is now an emerging risk concern. Nevertheless, women are somewhat more vulnerable than male workers for numerous reasons. As previously mentioned, women employed in this sector originate from rural as well as disenfranchised and disadvantaged family backgrounds. Their comparatively poor socio-economic settings results in a lack of 
organization/agency in which they are unable to plea for better working settings. They are paid less than their male fellow workers and are frequently exposed to physical and verbal abuse, violent sexual harassment and behaviour, informal recruitment, etc. (Akram, 2014; Choudhury, Luthfa, \& Gayen, 2016; D. S. Chowdhury, 2017; M. M. Hasan et al., 2018; Mottaleb \& Sonobe, 2011; Paul-Majumder \& Begum, 2000). Women are already viewed as weaker vessels within the traditional male-dominated Bangladeshi society, with tightly controlled social and economic lives and less physical ability. Due to these reasons, women workers are more eager to accept the exploitative type of job, where women are usually placed in low position due to social and cultural structures. Also, in more physically risky employment, the occupational hazards are greater (chemicals or materials) since they have few choices for independent earning (Kabir et al., 2018; Paul-Majumder \& Begum, 2000). From a macro viewpoint, sexual harassment represents a significant barrier to women's integration in the labour market. In other words, it obstructs the accomplishment of economic growth and gender equality (Siddiqi, 2003).

Many socio-economic and demographic issues have played an important role in influencing STIs and HIV in FGWs life in Bangladesh.

\section{STIs/HIV and its Impact on Women in Bangladesh}

Literature on sexually transmitted infection (STIs) stated that Bangladesh has a very high prevalence of STIs (sexually transmitted infection) which indicates the country's increased susceptibility to HIV (Mahmood, 2001). Bangladesh is one of the channels of the 'Golden Triangle'. Heroin is quite easily available, and it is feared that today's inhalers may in course of time be converted to 'injectors' (Choudhury MR, Chowdhury AQMB, \& S., 1995). Thus, they are more likely to become HIV positive.

NGOs and government clinics are providing voluntary counselling and testing services. However, due to the inadequate access to voluntary counselling and testing services as well as the stigma on human immunodeficiency virus (HIV) and acquired immune deficiency syndrome (AIDS), very few people of Bangladesh are aware of their HIV status (UNICEF, 2010). Although several people have heard of HIV, but their knowledge is limited in respect to how it is transmitted, including women of Bangladesh. Here, this refers to the socio-economic positions of the poor women of Bangladesh, and their knowledge about different infections, including STIs and HIV is extremely poor.

Infections with STIs increase the chance of spreading HIV. Effective treatment of STIs is one of the proven methods of preventing HIV (M. Hossain, Mani, Sidik, Shahar, \& Islam, 2014; M. Mofizul Islam, Conigrave, Miah, \& Kalam, 2010; Mondal, Hossain, \& Rahman, 2008). 
About $40 \%$ of the people of Bangladesh live under the poverty line, and the occurrence of poverty is highest among women (World Bank, 2008). $48 \%$ of boys and $55 \%$ of adolescent girls are enrolled in secondary schools and $90 \%$ of garment workers are female, of which $50 \%$ are adolescent girls. Bangladeshi adolescent population covers more $1 / 5$ of the total population, which constitutes 36 million (Bhattacharjee, 2018; Tamanna, 2019) Chowdhury \& Ullah, 2010). Without FGWs earnings, $80 \%$ of their families would fall below the poverty line (Majumder \& Zohir, 1995).Women's insufficient knowledge on STIs exerts a huge toll on not only a woman and her children/household, but also delays national progress at large (Yaya, Bishwajit, Danhoundo, Shah, \& Ekholuenetale, 2016), Symptoms of STIs such as vaginal discharge and genital ulcer disease were predominant, while risk behaviours such as multiple sex partners, drug abuse, and low use of condoms were also found (Mahmood, 2019; Sayem, 2010).

Approximately half a million poor socio-economic men meet every day with sex workers throughout the country. FGWs, rickshaw pullers, and truck drivers are three socio-economically disadvantaged illiterate risk groups, who regularly engage in illegal and unsafe sex by poor socio-economic men (A. T. M. H. Hasan, Hassan, Khan, Nuzhat, \& Hassan, 2013). Hossain and Chatterjee estimate that there are 100,000 female sex workers across Bangladesh (Hosain \& Chatterjee, 2005). GOB surveillance strategies are concentrated on 'key populations' female sex workers, injecting drug users (IDUs), and men who have sex with men (Md Mofizul Islam \& Conigrave, 2008; Population Council, 2018). A comprehensive literature search has revealed that no data on general women's STI and HIV prevalence in Bangladesh is available except more general data collected by the government surveillance (M. Mofizul Islam, Conigrave, Conigrave, \& Islam; UNAIDS, 2019). Thus, it is difficult to maintain a persuasive prevalence of STI among general women with less than $0.1 \%$ of females situated or being considered within the category.

Women are victims of various abuses including sexual ones, and their overall, gender-related status, and corresponding acknowledgement is lower than that of men in Bangladesh. In the same socio-economic and cultural context, women have lower access to health care and related policies. In general terms, they are not encouraged to talk on personal sexual and healthrelated issues. Correspondingly, only quantitative research focusing on women is frequently in the position to provide responses to particular issues focussing on women per se.

\section{Female Garment Workers and their Susceptibility to STIs/HIV}

Recent surveillance has revealed the presence of close sexual networks of IDUs with other high- risk groups, especially female sex workers (FSWs). 
Conversely, FSWs were shown to have close sexual links with multiple male client groups, not limited to IDUs (NASP, 2004). HIV is an increasing trend (Azim et al., 2008) among people who inject drugs (PWID) (Mahmood, 2007). FGWs who had sex with many partners were more likely to inject drugs, and these FGWs with many sex partners who had injected drugs were significantly less likely to use condoms (Sayem, 2010). Thus, the HIV-related risk behaviours of the FGWs may have a substantial influence on the future direction of the HIV epidemic in Bangladesh.

The adolescent FGW's characteristics with "formation of one's individuality, expressions of intimacy, and the defining of experiences within a sexual and romantic framework" (O'Sullivan \& Brooks-Gunn, 2005) make these FGWs particularly susceptible to social magnitudes, including potential risk of contracting STIs. Risk of contracting STIs, i.e., lack of knowledge about safe sex practice, multiple sex partners and having STIs without the knowledge of having it, have been known in Bangladeshi garment workers (Rianon et al., 2009). Another finding suggests that the respondents are not sufficiently conscious about contraceptive use, but contraceptive usage was found to be an important factor for STIs /HIV awareness (Mondal, Islam, Rahman, Rahman, \& Hoque, 2012). Another study reveals knowledge on noncontraceptive use of condoms for protection from STIs/HIV, syphilis, gonorrhoea, and other sexual transmitted diseases. Literature demonstrated that around $87 \%$ workers had no idea about these infections and only $13 \%$ were concerned of other uses of condoms (Sharmin, MohdIsa, \& Manan, 2014). Secondary educated FGWs have additional knowledge and awareness about STIs/HIV than illiterate FGWs (A. T. M. H. Hasan et al., 2013).

One study revealed that among FGWs, the high rates of intimate partner violence (IPV) was 69\%. 73\% experienced or witnessed workplace partner violence (WPV) and 40\% experienced depressive symptomatology (Parvin, Al Mamun, Gibbs, Jewkes, \& Naved, 2018). There is indication of adverse consequences of WPV on workers' physical and mental health (De Puy et al., 2015; Hansen et al., 2006) as well as job performance (Lin et al., 2015). The knowledge level is low, and FGWs are not knowledgeable about safe sex, contraceptive methods, menstruation, STIs, and HIV. Since there is enormous range of social insecurity, these adolescent FGWs are often victims of serious sexual abuse. Thus, FGWs are considered as vulnerable as any other key population and disenfranchised group for HIV infection in Bangladesh (Jahan, 2012; Mahmood, 2020). While there is wide recognition of IPV as a vigorous human rights and public health concern, indication for IPV prevention is still uncommon (Naved, Mamun, Mourin, \& Parvin, 2018). Globally, Bangladesh stands second when it comes to violence against women by men according to United Nation Population Fund (UNFPA) (Mahmood, 2004). 


\section{Bangladesh Garment Manufacturers' and Exporters' Association (BGMEA)}

Bangladesh Garment Manufacturers and Exporters Association also known as BGMEA, the leading organisation established by the garment manufacturers in 1982, plays an important role in the interests of garment factory owners and exporters and in serving common needs (M. M. Hasan et al., 2018; M. R. Islam, 2013; M Yunus \& T Yamagata, 2012). As the RMG industry is managing so well in regards to its export operations, it is thoughtprovoking to examine its contribution to the social circumstances of its workers, particularly its FGWs. BGMEA have 4,482 members (BGMEA, 2017). However, there are number of factories, who are not a member of BGMEA (Khan \& Wichterich, 2015). The main representative body for the owners 'BGMEA' has replied to workers' concerns. According to a BGMEA 1998 Newsletter titled 'Meets garment sector trade union leaders regularly', BGMEA representatives and leaders from workers' unions in the garment sector discussions emphasized on generating enhanced industrial relations. As a result, this leads to a smoother progression in the RMG sector by finding harmonious resolutions to industrial disagreements in the sector. According to another 1998 newsletter, it was mentioned that the BGMEA is also attempting to assist with housing and other services for garment labours. Three housing projects for Dhaka garment workers were being considered by BGMEA, which was assisted by international donor agencies, such as the International Labour Organisation (ILO), the United Nations Development Programme (UNDP), and UNICEF (Absar, 2001).

In the same newsletter, the then BGMEA President uttered that new measures and steps would be introduced by regular medical check-ups for 1.5 million garment workers. However, the promises and agreements have not delivered as much as they should (Absar, 2001; M. M. Hasan et al., 2018; IFC, 2014; M. S. Islam et al., 2016; T. Islam, 1998; J. Siddiqui \& Uddin, 2016). This is predominantly due to wide-ranging labour law violations, overwork, and uncongenial working condition.

The GOB increasingly driven by export oriented economic policies has limited its role to watching from the sideline (Shamsul Khan, 2001). Networks of the garment industrial owners have been more powerful and influential (Absar, 2001). However, there are currently very few female factory owners' in Bangladesh (Perman \& David, 2004). Owing to their power, work hour restrictions, workers' pension schemes, minimum wages, and limited fringe benefits have not been implemented. The then BGMEA Director in 2000 promised the participants (workers, researchers and union leaders) in a garment industry conference that BGMEA would resolve problems rising typically from insecurity of the job, irregular payments, factory transportation, and violations of labour laws, particularly in subjects related to maternity and 
leave benefits (Absar, 2001). Executive director of the Policy Research Institute stressed that the factory owners should also take steps to increase the efficiency of the workers by building a strong mid-level management and safeguarding the best use of water resources (Mirdha, 2015). In Bangladesh, $66 \%$ of workers reported that overtime is mandatory. According to Bangladesh labour law, no FGWs should be made to work without their consent between the hours of $10 \mathrm{pm}$ and $6 \mathrm{am}$, and no young worker should be permitted to work in any establishment between the hours of evening ( 7 $\mathrm{pm}$ ) to morning (7 am). However, garment workers in some RMG industries indicated that both male and FGWs are often forced to work during night shifts (Bhattacharjee, 2018).

\section{Trade Unions}

In Bangladesh, the trade union movement is weak and is male oriented. There are 5 trade unions (R Afsar, 1998) but FGWs were reluctant to join trade unions (N. J. Chowdhury \& Ullah, 2010; Das, 2008). A survey revealed that $56 \%$ of the FGWs said that trade union did not exist in their factories because the owners and management were extremely opposed to any types of unionization of their workforce. $36 \%$ of the FGWs reported that although trade union existed in their factories, the leaders of the union are controlled. Trade union does not work for the workers but only serves the interest of the owners of the garment factories (N. J. Chowdhury \& Ullah, 2010; SI Khan, 2001), leaving FGWs owner with limited ways to address their health concerns.

According to (Shamsul Khan, 2001), the Industrial Relations Ordinance of 1969 delivers several avenues for workers' participation in management. Khan adds that such participation programs have largely failed to generate the desired outcome in the private sector because the majority garment manufacturers fear that it will unsurprisingly lead to an unhealthy collusion between trade unions and political parties. This will consecutively hamper developments in terms of productivity and the formation of a friendly working environment.

\section{Labour Policy}

It appears that the reasonable advantage of cheap labour and the cost of production in the international competition and international market are the main reasons for the reluctance or failure to enforce labour laws and policies in Bangladesh (Absar, 2001; Paul-Majumder, 1997). Furthermore, most of the garment factories of Bangladesh do not comply with international and national standards such as those for minimum standards recommended in building and construction, safe working environment, labour rights, etc. (Barua \& Ansary, 2017). Many members of parliament are factory owners, who will influence the GOB into doing what is best for them (Magendans, 2014). 
Cultural norms, discrimination by factory owners, and trade union all help to explain FGWs' exclusion from the broader labour market, the past by a policy environment, and local 'mastans' (A. Muhammad, 2011) which protected factory owners from the outcomes of such discrimination (Kabeer $\&$ Mahmud, 2004b). Some scholars asserted that the primary cause of feminization and labour vulnerability is the gendered discourses of the study (M. I. Hossain, Mathbor, \& Semenza, 2013). The gendered discourses of labour refer to the gender biased beliefs that "provide distinct forms of labour for men and women'. These beliefs explain gender discrimination and labor exploitation at the workplace (Caraway, 2005). Both "economic choices of cheap labour" and "gendered discourses of work" jointly impose the feminized pattern of the labour force, which eventually leads to the violation of labor rights that serve the economic cause of cheap labour (M. I. Hossain et al., 2013). Indeed, most FGWs do not know that they have labour rights (Siddiqi, 2003), and there is not much application of the laws in their garment factories (S. Mahmud, 2010). However, there are law courts to which FGWs and management can turn to for judgement of disagreements, but these are timeconsuming and expensive (Siddiqi, 2003).

The ILO identifies sexual harassment as a 'violation of the fundamental rights of workers', which constitutes a dilemma of health and safety, a dilemma of discrimination, 'an unacceptable working condition and a form of violence' (ILO, 2004). The ILO Conditions (1992) of Work Digest published Combating Sexual Harassment at Work, which was approved from industrialized countries on dealings to combat sexual harassment (ILO, 2019). The Nari O Shishu Nirjaton Domon Ain law prepared sexual harassment as a criminal offence (Siddiqi, 2003) in the year 2000. Nevertheless, much of the labour legislation is not only inappropriate to the vast mainstream of the country's workforces, but it is also outdated/obsolete and vulnerable to misapprehension, and does not have special terms for the workplace (Kabeer \& Mahmud, 2004b; Siddiqi, 2003). The 2006 Bangladesh Labour Law does not mention any sexual harassment as such, although it disallows discrimination on the foundation of "sex, colour and creed" (GTZ, 2007). In the meantime, occurrences of sexual violence against women that are employed as FGWs have risen (Siddiqi, 2003). In 1998, while FGWs accounted for only $2-3 \%$ of the total population of women in Dhaka Metropolitan area, they accounted for a disproportionately high $11 \%$ of rape cases (Paul-Majumder \& Begum, 2000). This practice of sexual violence includes the owners, close male relatives of owners, supervisory staff, production managers, and buyers with attractive young FGWs who are most vulnerable (Siddiqi, 2003). The GOB has been following a limited protective policy only in consideration of numerous vital issues such as public health, security, and religious restrictions (Rahman, 2008). The explanation for most 
of the sexual harassment of the FGWs is that because of their occupation, these FGWs are 'easy virtue' (Siddiqi, 2003). One study revealed that almost 43\% personnel and/or owners of the garment factory answered that sexual harassment does not influence their factory growth and monitory development (M. M. Hasan et al., 2018).

\section{National Tripartite Plan of Action}

After the Rana Plaza disaster in 2013, where more than 1100 garment workers were killed, the GOB set in place several incentives to ease the problems and difficulties faced by RMG owners. These include bringing down the advance income tax from $0.8 \%$ to $0.3 \%$, arrangement of low-cost credit for struggling RMG units, etc. However, these incentives were not sufficient to fulfil the requirement of global buyers for safer conditions. Hence, tripartite partners - the GOB, RMG workers and RMG owners - signed a joint statement in May 2013. Also, they formed a national tripartite plan of action (NTPA) on fire safety and structural integrity in the RMG sector of Bangladesh in July 2013. This included 25 commitments divided into three categories, namely: legislation and policy, administration, and practical activities. The committee chaired by the labour secretary includes GOB agencies, employers, Bangladesh Garment Manufacturers \& Exporters Association (BGMEA), Bangladesh Employer's Federation (BEF), Bangladesh Knitwear Manufacturers \& Exporters Association (BKMEA), and trade unions (Gomes, 2013). Furthermore, the 'Rana Plaza factory disaster' brought about two agreements (legally binding and non-legally binding) for standardizing and regulating workplaces. However, most of the buyers have contracted the non-legally binding agreement (Karim, Shah, \& Salleh, 2014). The NTPA, along with the European Union Sustainability Compact agreed to improve labour rights and factory safety (Higginbottom, 2004), which helped to improve the working environment of garment industry, but in the same time less emphasis is given on ensuring other health and safety issues (Prentice \& De Neve, 2017). In one study it was revealed that FGWs freedom of association is still ignored in NTPA factories and Contribution of NTPA is not significant. The NTPA, was a rather powerless and weak institution in the GOB. Additionally, continuous rampant corruption and bureaucracy red tape hindered an effective administration (Khan \& Wichterich, 2015). Corruption is widespread in Bangladesh. According to Transparency International (2014), Bangladesh ranks second on perceived corruption of clothing exporters (Magendans, 2014). 


\section{Discussion}

\section{Bank Loan to RMG Industries}

The challenge is that the factory owners require a huge amount of money, and they are insolvent and eager to remedy factory safety. As a result, the RMG factory owners have demanded the formation of long-term loan instruments. In reply to such a demand, different organizations such as Agence Française de Développement (AFD), International Finance Corporation (IFC) US, and the Alliance and Japan International Cooperation Agency (JICA) all provided loans to the local banks. These banks will distribute the loans to the garment factory owners to develop their fire safety infrastructure, structural infrastructure, and electrical infrastructure. The GOB has made plans to set up a specific bank for the garment factories to deliver easy loans (ILO, 2017). While this is a good initiative, the challenge lies in the fact that these financial supports are not adequate compared with the requirement (Barua \& Ansary, 2017).

\section{Capacity Building on HIV/STIs and IPV/WPV through Workplace Intervention}

Limited progress was detected in several commitments such as protection of labour rights, education, training programmes for capacitybuilding, remediation works in factories, rehabilitation and reemployment of affected garment workers, etc. (Barua \& Ansary, 2017). In the garment factories, on-the-job training is the only training facility that was provided to them. In 1995, BGMEA undertook a training program, which was sponsored by ILO/UNDP and only $20 \%$ of the trainees were females, although women make up the majority of workers in the garment factories (Paul-Majumder, 1997). Another source articulated that BGMEA runs several programs with non-profit organizations to provide information on health issues, including HIV/STIs among the FGWs through workplace interventions (The Korea Times, 2013). In 2017, Bangladesh Export Processing Zones Authority (BEZPA) undertook a similar kind of training, which was sponsored by World Bank, called 'NARI' which provided training, transitional housing, counselling, and job placement services in garment factories (World Bank, 2017). However, the Bangladesh Independent Garments Union Federation (BIGUF) and/or BEPZA has no clear programmes on sexual harassment or on WPV and IPV training (ILO, 2019; World Bank, 2017). It suggested that male partners should be incorporated in HIV prevention programmes. Interventions concentrating on education regarding HIV transmission and condom negotiation skills are inadequate for several of these migrant women, since implementation necessitates male collaboration (Bjelland et al., 2010). Due to their low level educational and poor economic strata, these further make the FCWs susceptible to STIs/HIV. Therefore policymakers and owners must 
offer satisfactory incentives and awareness related training to benefit the healthcare and economic conditions of this vulnerable group (Hasnain et al., 2014). Internationally renowned physician-scientists should explore the potential for new HIV prevention strategies and detailed tailored interventions are needed to curb the epidemic among targeted populations (Mahmood, 2010), including FGWs in Bangladesh.

In Bangladesh, IPV is outlawed through '2010 Domestic Violence Act'. Nonetheless, there remain significant encounters in application, along with the continuing opinion that domestic violence is a private concern (Naved, Rahman, Willan, Jewkes, \& Gibbs, 2018). Berik and Rodgers (2008) referred that Bangladesh garment factory owners' are very reluctant to invest in training and development facilities, although it revealed that training overheads are directly offset by the productivity increase (Berik \& Rodgers, 2010).

Sexual harassment worsens the vulnerability of the female workforce and this reduces their opportunities, benefits, and rights in the Bangladeshi RMG sector (D. S. Chowdhury, 2017). In 2019 at a National Conference, the researchers stated that sexual and reproductive health and rights (SRHR) is a neglected issue in Bangladesh, and Bangladeshi people need to alter their attitude to work on the SRHR matters. Furthermore, Bangladesh must grasp key initiatives for the SRHR needs of the FGWs. Also, safeguarding SRHR is vital to attain SDGs. In this national conference, the researchers also discussed neglected issues of SRHR such as gender based violence and HIV/AIDS at the workplace, correspondingly adolescent commitment in indorsing SRHR service, and education (Dhaka Tribune, 2019; Tamanna, 2019). Gender based violence is about power, and it is not going to end until FGWs can easily establish and bargain jointly to take that power back (Revolution, 2019).

In the 3rd International conference on AIDS in Asia and Pacific, Dr. Piot predominantly emphasised the importance of 'education' to younger cohort before they are sexually active. This is because in many countries, such programmes result in the postponement of first intercourse. He also comprehended the importance of the workplace programmes tackling the HIV/AIDS related issues, where the owners and the FGWs could be exposed to the impacts (Choudhury MR \& Stefano, 1995).

Numerous researchers establish that the workplace environment in the garment factories is below the ILO standard (M. I. Bhuiyan, 2013). Nevertheless, work place health interventions are slowly being acknowledged as useful for both owners and FGWs (Baicker, Cutler, \& Song, 2010).

\section{The Role of Government and Business Sector}

In the same conference, Dr. Piot's concluding remarks was that "we should expand our response beyond traditional intervention \& beyond 
traditional sectors \& partners. We need far more to empower individuals \& enable communities to modify the broader context of behaviour that encompass among others the social, political \& cultural aspects”. He also suggested the need to raise cooperation between government and business sectors because both power and wealth are required for the fight against HIV/AIDS. It is for this reason that the business sector should be well represented in the National AIDS Control Council in every country (Choudhury MR \& Stefano, 1995).

\section{Safety and Security and FGWs}

The GOB, together with the factory owners, were accused of "criminal negligence" due to their failure to make these factories answerable or to safeguard the rights of basic workers (Gomes, 2013; Kernaghan, 2012). The factory owners are responsible for providing safe working environment. However, working conditions are safe, only when the FGWs and their owners'/supervisors' participate and cooperate (Galib, Khan, Kabir, \& Zubayer). Furthermore, 'Ready Made Garment factory owners continue to violate the safety and security of the workplace and maintain inhumane working conditions' (J. Siddiqui \& Uddin, 2016). In one study it was revealed that garment factory owners have shown few signs of recognising their interests to support better state education for FGWs, better public safety for FGWs, and to change their management practices to better retain and raise productivity of skilled FGWs (N. Hossain, 2012).

\section{Termination Options and FGWs}

Generally, garment factory owners' have been hesitant to allow the creation of trade unions. According to ILO (1995), the Bangladesh Independent Garments Workers Union which was founded in 1995 refused registration as a national union due to concerns raised by garment factory owners (J. Siddiqui \& Uddin, 2016). As a result, owners of the garment factory can easily terminate FGWs and appoint new garment workers and deprive them of their rights (N. U. Muhammad, 2012). To resolve the problems, all the parties related to the industry, FGWs, owners' and GOB have to work together (M. S. Mahmud \& Rajath, 2017).

\section{HIV and the Gradients of Power for FGWs}

HIV is spreading along "the gradients of power" and it is endlessly created and recreated by wide-ranging economic, political and social forces (Farmer, 2001). The limited purchasing power of women garment workers defines and limits their access to health, housing, sanitation, and transportation facilities. It also has consequences of limiting the autonomy of women and strengthening male power. Lack of job security is compounded by low 
salaries, which causes insecurity of life for women in urban areas. Nevertheless, women continue to work, and the explanations for this are obvious in the narratives (Shamsul Khan, 2001). Private-sector involvement and garment factory owners involvement in the HIV and AIDS epidemic needs to be encouraged and explored, (Campaign, 2012; Nidhi, 2009). Bangladeshi garment factory owners put the lives of million garment workers in danger, even though these owners are dependent on this manual workforce for their business to flourish (Choudhury et al., 2016). Since workers in garment factories are overwhelmingly female, addressing the STIs/HIV vulnerability on FGWs can improve the overall health of women (Mohd Hajaraih, Gordon, \& Tabb, 2019). Al Gore, former vice president of United States of America once stated in 2004, "We hope that justice, not power, can supplant suppression. As Lincoln said in his greatest trial, 'We, even we here, hold the power and bear the responsibility'" (Mahmood, 2005). Thus, we honour Dr. Martin Luther King's influence on American society, and his enduring impact on social justice. Dr. King once said that "injustice anywhere is a threat to justice everywhere" (Christina Quint, 2020). Now more than ever, we must turn to make right one of the greatest social injustices of our time -empowering women.

\section{Monetary Priorities and FGWs}

In Bangladesh, most garment owners failed to see any fundamental connection between productivity outcomes and labour standards. As a result of their monetary priorities, many garment owners have become virulently anti-trade union and they believe that trade unions would upset Bangladesh's low-wage employment structure, which is crucial for maintaining Bangladesh's magnetism to foreign financiers (Shamsul Khan, 2001). Thus, the vital step would be reinforcing trade unions as a way to enforce industrial and labour laws and regulations and offer better protection measures for the FGWs. In other words, trade unions of the garment factories should be independent. Furthermore, the GOB should take some policies to meet up financial crisis and should monitor whether labour laws are followed by the garment factory owners. Moreover, the garment factory owners should maintain a good relationship with the FGWs to ensure the sustainable development of this sector (M. M. Hasan et al., 2018). In 2009, Bangladesh began to formalise legislation and policies, following a High Court ruling which established that laws were insufficient in covering sexual harassment in the work place (Gibbs et al., 2019). The GOB should dedicate resources to enforce existing labour laws. In addition, it should enforce punishment for noncompliance with labour laws. Many FGWs are excluded from the application of existing labour laws because their jobs are seasonal or temporary. Furthermore, many existing labour laws do not comply with the 
dynamic requirements of export-oriented industrialization (Paul-Majumder \& Begum, 2000). In Bangladesh, the garment industries continue to develop in spite of high levels of corruption. A typical wisdom is that corruption is a confront on production that damages business effectiveness (Kreps, 1997). In one study, it was indicated that Courrnot competition can lead to corruption of a garment industry (Sato, 2014).

\section{Health Centres and FGWs}

The GOB should establish health centres at the locations where the garment factories are clustered. Health centres in clustered locations would help the FGWs to gain access to health facilities without spending much time (Paul-Majumder \& Begum, 2000). Moreover, involving policymakers to ensure compliance with suitable industrial healthcare provisions by the factory owners and international buyers will help improve primary healthcare of the FGWs (Solinap et al., 2018). Owners of the garment factories should be encouraged to invest in the health of FGWs by providing tax rebate or tax holiday as incentives (Begum, Ali, Hossain, \& Shahid, 2010).

\section{Existing Law and FGWs}

Upgrading existing law on health and safety requirements, such as the 1965 Bangladesh Factories Law, which entails factories to provide health, hygiene and safety, is vital at this time. However, these corrective processes are often expensive and time consuming. Dividing the responsibility of the factory owners with international buyers and organizations is essential to ensure the well-being of the FGWs in Bangladesh and in low and middle income countries (Solinap et al., 2018). Paradoxically, better health conditions for the FGWs would benefit the factory owners and the economy in the long term. For example, if FGWs do not get sick, then they will be able to continue to work throughout the year, which would boost RMG productions (Haque et al., 2008).

The former Executive Director and co-discoverer of Ebola virus, Dr. Peter Piot in an interdisciplinary international conference on AIDS- Law and Humanity, held in December 6-10, 1995, indicated the narratives below in his forwarding letter ".......Deeply interwoven in both the roots and ramifications of HIV/AIDS are ethical issues. These range from the individual and community human rights, violations that render people more vulnerable to infection, to the stigma and discrimination which needlessly compound the suffering of those affected by HIV/AIDS. In the AIDS era - which is likely to last for decades or even longer-only law that is truly comprehensive in scope can afford the necessary protection to individuals and society alike" (Piot, 1995). 


\section{Labour Code Amendment and FGWs}

In Lesotho, a number of adjustments have been made, such as the Labour Code Amendment Act (2000), which established the Directorate for Dispute Prevention. Also, Resolution and Labour Code Amendment Act (2006) introduced provisions on HIV/AIDS and transferred jurisdiction for specific types of employment disputes from the Labour Appeals Court to the Labour Court (Irene, 2014). Furthermore, Morshed advocates the basic role of Cambodian labour unions in the garment factories and as facilitators between FGWs and garment factory owners to discuss wages and settle disputes (Morshed, 2007; N. U. Muhammad, 2012). In one study it was indicated that Amendment of Labour Law of Bangladesh did not help in acceleration of setting up unions (Khan \& Wichterich, 2015). Another cause of labour unrest in the garment factories: FGWs lack of feeling of ownership (Mohammad Yunus \& Tatsufumi Yamagata, 2012)

\section{Good Governance and FGWs}

Diseases, such as HIV/AIDS, pose as much of an epidemiological challenge just as the challenge of good governance. No country has been able to eliminate this dangerous deadly scourge. Nevertheless, it is possible to keep it under control (Mahmood, 2006). Good governance is important in ensuring effective health care delivery. Also, returns to investments in health are low, where governance issues are not addressed. Strengthening the health system through better management and organization and effective use of resources can improve health conditions and enhance the quality of health care delivery (Mahmood, 2012).

\section{Future Research}

Schwandt (2005) combated the use of the positivists approach to the social sciences since the acts of people are not connected to the general laws of environment, being highly multifaceted and dependent on their emotions habits, beliefs, and rationales (Schwandt, 2005). Consequently, this is also reflected on the garment factory owner's perception towards FGWs health, especially on STIs/ HIV.

Future research on this area should target an ethnographical qualitative research approach to explain the perceptions which appeals on sociological rational about the dynamics of organisational procedures related to it (M. F. Chowdhury, 2014). This type of study based approach was suggested by Yin (2009) and Leedy (1997), which necessitate a detailed focus of the social science capacity to comprehend its occurrence on the source of it being an individual dilemma. All future approaches and intervention for prevention of STIs/HIV should be based on realistic information regarding the dynamics of sexuality and sexual behaviours, which is constructed in local socio-cultural, 
socio-economic, psycho-social, and spiritual context (Sharful Islam \& Faisel, 1997). To perform a vigorous research in this area, study based approach would provide the investigators flexibility and would ensure that the responses of the research questions are investigated through a variety of lenses, instead of one lens (Leedy \& Ormrod, 2001). Thus, this would allow for numerous aspects of the occurrences to be disclosed and recognized (Baxter \& Jack, 2008).

\section{Conclusion}

A healthy workforce is not only a step towards empowering a business, but it also empowers the economy of the society and decreases the burden of health care costs so as to empower the health of women in general (Rianon et al., 2009). The GOB, international rights-based organizations, BGMEA and owners' of garment industry should use these findings to create a dialogue to develop strategies to improve this significant component of the working environment. Moreover, designing and implementing behaviour change interventions is required, particularly for the supervisors and owners' to improve the situation. (Akhter, Rutherford, \& Chu, 2019). BGMEA should facilitate programmes on sexual harassment, along with IPV and WPV training in every garment factories in Bangladesh so that the lives of these vulnerable and disenfranchised groups can be empowered and protected. In other words, there should be an increased level of education, and awareness about labour rights and sexual harassment of the FGWs should be kept at a minimum level. In addition, this will decrease the susceptibility towards STIs/HIV. It is also vital to push for greater implementation of the 'Domestic Violence Act 2010'. Therefore, the GOB and BGMEA should be aware of the violation of the law against these poor, vulnerable, and disenfranchised FGWs.

Subsequently, equal opportunity to both male and female workers should be provided. There should not be any gender discrimination. All FGWs should have access to be a part of this union and can voice their rights and necessities. FGWs should also be trained on their rights in collaboration with trade union. In other words, a female representative is to be ensured in the leadership of the trade union. BGMEA can play a pivotal role in this connection. No FGWs should be made to work without their consent over time, including night shifts. Moreover, the GOB should include health safety, including STIs/HIV strategy plan in NTPA.

This review recognized that owners, BGMEA, researchers, GOB, and policy makers in Bangladesh should seek to address the health of FGWs, particularly STIs/HIV issues and can help a lot to solve the problem and continue the success story.

In conclusion, the GOB must formulate and implement safety and health policies for FGWs. All garment factories in Bangladesh should be a 
member of BGMEA. The GOB and garment factory owners along with BGMEA should take steps to operate mobile courts in factory level to ensure FGWs safety and also ensure that health-related rules and regulations are followed. Trade union of Bangladesh should follow Lesotho Act procedure and work as facilitators between FGWs and garment factory owners to discuss wages and other pressing issues and settle disputes. Health, hygiene, safety, and sanitation factors at workplace need to be improved. Bonus systems should be increased. The GOB enforcement agency should monitor regularly whether any financial corruption is involved with factory owners and BGMEA on the subject of owners benefit and vice versa. Donor community and local banks can come forward to assist them financially so that their health can be ensured. Above all, FGWs (100\% participations), including male partners and the owners of the factories should be involved in HIV and IPV/WPV related prevention programme.

\section{Authors' Contributions}

SM designed and conducted the literature review and methodology. He also contributed to the manuscript structure as well as the drafting and overall editing of the manuscript. The author read and approved the final manuscript.

\section{Acknowledgements}

The author expresses his sincere gratitude to Prof. Daniela Heil and Dr. Chris Krogh, School of Humanities and Social Science, Faculty of Education and Arts, University of Newcastle for their encouragement in writing this manuscript and the reviewers appointed by the ESJ for their useful comment.

\section{Conflicts of Interests}

The research received no specific grant from any funding agency in the public, commercial or not-for-profit sectors. The author declares no conflicts of interest.

\section{References:}

1. Absar, S. S. (2001). Problems surrounding wages: the ready made garments sector in Bangladesh.

2. Afsar, R. (1998). Poverty, Work, Health and Sexual Behaviour of Women and Men in Garment Factories in Dhaka, Bangladesh. Bangladesh: ACTIONAID.

3. Afsar, R. (2000). Female Labor Migration and Urban Adaptation: BIDS.

4. Ahamed, F. (2013). Could monitoring and surveillance be useful to establish social compliance in the ready-made garment (RMG) 
industry of Bangladesh. International Journal of Management and Business Studies, 3(3), 88-100.

5. Ahmed, F., Hasan, N., \& Kabir, Y. (1997). Vitamin A deficiency among adolescent female garment factory workers in Bangladesh. European Journal of Clinical Nutrition, 51(10), 698-702.

6. Ahmed, F. E. (2004). The rise of the Bangladesh garment industry: Globalization, women workers, and voice. NWSA journal, 34-45.

7. Ahmed, S., \& Raihan, M. Z. (2014). Health status of the female workers in the garment sector of Bangladesh. J Faculty Econom Administr Sci, 4(1), 43-58.

8. Akhter, S., Rutherford, S., \& Chu, C. (2019). Sufferings in silence: Violence against female workers in the ready-made garment industry in Bangladesh: A qualitative exploration. Women's Health, 15, 1745506519891302. doi:10.1177/1745506519891302

9. Akram, O. (2014). Occupational health, safety and extreme poverty: a qualitative perspective from Bangladesh. International Journal of Occupational Safety and Health, 4(1), 41-50.

10. Azad, M. A. K. (2014). Satisfaction of Garments Workers towards Current Salary Structure in Bangladesh: An Analysis. Journal of Business, 35(2).

11. Azim, T., Chowdhury, E. I., Reza, M., Faruque, M. O., Ahmed, G., Khan, R., . . Strathdee, S. A. (2008). Prevalence of Infections, HIV Risk Behaviors and Factors Associated with HIV Infection Among Male Injecting Drug Users Attending a Needle/Syringe Exchange Program in Dhaka, Bangladesh. Substance Use \& Misuse, 43(14), 2124-2144.

12. Baicker, K., Cutler, D., \& Song, Z. R. (2010). Workplace Wellness Programs Can Generate Savings. Health Affairs, 29(2), 8. doi: 10.1377/hlthaff.2009.0626

13. Barua, U., \& Ansary, M. A. (2017). Workplace safety in Bangladesh ready-made garment sector: 3 years after the Rana Plaza collapse. International Journal of Occupational Safety and Ergonomics, 23(4), 578-583.

14. Baxter, P., \& Jack, S. (2008). Qualitative case study methodology: Study design and implementation for novice researchers. The qualitative report, 13(4), 544-559.

15. Begum, F., Ali, R., Hossain, M., \& , \& Shahid, S. (2010). Harassment of women garment workers in Bangladesh Journal of the Bangladesh Agricultural University, 8(2), 291-296. doi:DOI: 10.3329/jbau.v8i2.7940

16. Berik, G., \& Rodgers, Y. V. D. M. (2010). Options for enforcing labour standards: Lessons from Bangladesh and Cambodia. Journal 
of International Development: The Journal of the Development Studies Association, 22(1), 56-85.

17. BGMEA. (2016). Trade Information. Bangladesh Garment Manufacturers and Exporters Association.

18. BGMEA. (2017). Bangladesh Garment Manufacturers and Exporters Association :Toward a Sustainable Garment Industry (BGMEA). Trade Information. Retrieved from http://www.bgmea.com.bd/home/pages/TradeInformation

19. Bhattacharjee, S. S. (2018). Gender Based Violence in the Walmart Garment Supply Chain. Retrieved from USA:

20. Bhattacharya, D., \& Rahman, M. (2000). Bangladesh's apparel sector: Growth trends and the post-MFA challenges. Paper presented at the Proceedings of a national seminar on the Growth of the Garment Industry in Bangladesh: Economic and Social Dimensions, BIDS and Oxfam Bangladesh, Dhaka.

21. Bheda, R. (2004). Improving working condition and Productivity in the Garment Industry. Contact Communications, Stitch World.

22. Bhuiyan, M. I. (2013). Reasonable Wages for Workers to Eliminate Unrest in Bangladesh's Readymade Garments (RMG) Sector. Fowler Street, USA: Bangladesh Development Research Center (BDRC).

23. Bhuiyan, Z. A. (2012). Present status of garment workers in Bangladesh: An analysis. IOSR Journal of Business and Management, 3(5), 38-44.

24. Bjelland, M. J., Bruyere, S. M., von Schrader, S., Houtenville, A. J., Ruiz-Quintanilla, A., \& Webber, D. A. (2010). Age and disability employment discrimination: occupational rehabilitation implications. Journal of Occupational Rehabilitation, 20(4), 456471 .

doi:https://dx.doi.org/10.1007/s10926-009-9194-z

25. Campaign, C. C. (2012). Hazardous workplaces: Making the Bangladesh Garment industry safe.

26. Caraway, T. L. (2005). The political economy of feminization: From "cheap labor" to gendered discourses of work. Politics \& Gender, 1(3), 399-429.

27. CHAN CHAO. (2016). Bangladesh textile industry sets export record. Retrieved from

https://www.chanchao.com.tw/DTG/newsDetail.asp?serno=588

28. Choudhury MR, Chowdhury AQMB, \& S., L. (1995). Responding to HIV-AIDS in Bangladesh. NAC, Dhaka, Bangladesh: National AIDS Committee. 
29. Choudhury MR, \& Stefano, L. (1995). A report on the 3rd International conference on AIDS in Asia and Pacificl The 5th National AIDS Seminer in Thailand. Dhaka: WHO \& NAC.

30. Choudhury, Z. A., Luthfa, S., \& Gayen, K. (2016). Vulnerable empowerment: Capabilities and vulnerabilities of female garments workers in Bangladesh: Bangladesh Mahila Parishad.

31. Chowdhury, D. S. (2017). Women's rights and voice in the readymade garments sector of Bangladesh: evidence from theory and practice. Journal of International Women's Studies, 18(2), 118-133.

32. Chowdhury, M. F. (2014). Deterrence theory and labelling of industrial accidents as white-collar crime in Bangladesh apparel industry: An epistemological standpoint. Perspectives of Innovations, Economics and Business, PIEB, 14(2), 69-82.

33. Chowdhury, N. J., \& Ullah, M. H. (2010). Socio-Economic Conditions of Female Garment Workers in Chittagong Metropolitan Area An Empirical Study. Journal of Business and Technology (Dhaka), 5(2), 53-70.

34. Christina Quint. (2020). Injustice Anywhere is a Threat to Justice Everywhere. salud sin dano.

35. Daily Star. (2016). Bangladesh can become no. 1 apparel exporter in a decade. Retrieved from https://www.thedailystar.net/business/bangladesh-can-become-no1-apparel-exporter-decade-1297279

36. Das, M. B. (2008). Whispers to voices: Gender and social transformation in Bangladesh. Retrieved from

37. De Puy, J., Romain-Glassey, N., Gut, M., Pascal, W., Mangin, P., \& Danuser, B. (2015). Clinically assessed consequences of workplace physical violence. International archives of occupational and environmental health, 88(2), 213-224.

38. Dhaka Tribune. (2019). Ensuring sexual and reproductive health and rights is important to attain SDGs'. Retrieved from

https://www.dhakatribune.com/feature/2019/09/22/ensuringsexual-and-reproductive-health-and-rights-is-important-to-attainsdgs

39. Drapers. (2017). Bangladesh to overtake China as largest clothing supplier by 2020. Retrieved from

https://www.drapersonline.com/news/bangladesh-to-overtakechina-as-largest-clothing-supplier-by-2020/7025921.article

40. Farmer, P. (2001). Infections and inequalities: The modern plagues: Univ of California Press.

41. Foundation, A. (2013). United Efforts, Not Boycotts, Will Help Bangladesh's Garment Workers. from The Asia Foundation 
http://asiafoundation.org/2013/05/15/united-efforts-not-boycottswill-help-bangladeshs-garment-workers/

42. FWF. (2013). Standing Firm against Factory Floor Harassment.

43. Gale, N. K., Heath, G., Cameron, E., Rashid, S., \& Redwood, S. (2013). Using the framework method for the analysis of qualitative data in multi-disciplinary health research. BMC Medical Research Methodology, 13(1), 1-8.

44. Galib, S. A., Khan, M. R. I., Kabir, M. H., \& Zubayer, S. (2019). A Study on the Occupational Safety and Health in Perspective of Disaster Management Approach: Research on Ready-Made Garments Sector of Bangladesh.

45. Gibbs, A., Jewkes, R., Willan, S., Al Mamun, M., Parvin, K., Yu, M., \& Naved, R. (2019). Workplace violence in Bangladesh's garment industry. Social Science \& Medicine, 235, 112383.

46. Gomes, W. (2013). Reason and responsibility: the Rana Plaza collapse. Open Security.

47. GTZ. (2007). Salient features of the Bangladesh labour law 2006 related to the $R M G$ sector Retrieved from

https://www.ilo.org/dyn/eplex/docs/12/Working_Paper__Labour_Law_2006-1.pdf

48. Hansen, А̊. M., Hogh, A., Persson, R., Karlson, B., Garde, A. H., \& Ørbaek, P. (2006). Bullying at work, health outcomes, and physiological stress response. Journal of psychosomatic research, 60(1), 63-72.

49. Haque, M. A., Begum, H. A., \& Fahmida, H. (2008). Supply-side effect of health care facilities on productivity amongst the female workers in the readymade garment sector. Ibrahim Medical College Journal, 2(1), 4-8.

50. Hasan, A. T. M. H., Hassan, R., Khan, Z. R., Nuzhat, E., \& Hassan, U. A. (2013). Influence of socio-demographic factors on awareness of HIV/AIDS among Bangladeshi garment workers. Springerplus, 2(1). doi:10.1186/2193-1801-2-174

51. Hasan, M. M., Parven, T., Khan, S., Mahmud, A., \& Yajuan, L. (2018). Trends and impacts of different barriers on Bangladeshi RMG industry's sustainable development. International Research Journal of Business Studies, 11(3), 245-260.

52. Hasnain, M. G., Akter, M., Sharafat, M. S. I., \& Mahmuda, A. (2014). Morbidity patterns, nutritional status, and healthcareseeking behavior of female garment workers in Bangladesh. Electronic physician, 6(2), 801.

53. Higginbottom, G. M. (2004). Sampling issues in qualitative research. Nurse Res, 12(1), 7-19. 
doi: $10.7748 / \mathrm{nr} 2004 \cdot 07 \cdot 12 \cdot 1.7 . c 5927$

54. Hosain, G. M. M., \& Chatterjee, N. (2005). Beliefs, sexual behaviours and preventive practices with respect to HIV/AIDS among commercial sex workers in Daulatdia, Bangladesh. Public Health, 119, 371-381. doi:10.1016/j.puhe.2004.08.015

55. Hossain, M., Mani, K. K. C., Sidik, S. M., Shahar, H. K., \& Islam, R. (2014). Knowledge and awareness about STDs among women in Bangladesh. BMC Public Health, 14, 775. doi:http://dx.doi.org/10.1186/1471-2458-14-775

56. Hossain, M. I., Mathbor, G. M., \& Semenza, R. (2013). Feminization and labor vulnerability in global manufacturing industries: Does gendered discourse matter? Asian Social Work and Policy Review, 7(3), 197-212.

57. Hossain, N. (2012). Exports, Equity, and Empowerment: The Effects Of Readymade Garments Manufacturing Employment On Gender Equality In Bangladesh Bangladesh. Retrieved from New York, USA:

file:///C:/Users/c3271781/Downloads/Exports_Equity_and_Empow erment_The_Effec.pdf

58. IFC. (2011). Fostering women's economic empowerment the case of Bangladesh. Washington, DC: The World Bank Group. Retrieved 2019, from The World Bank Group http://documents.worldbank.org/curated/en/653131468006880220/ pdf/727030WP0Box370and0women0bangladesh.pdf

59. IFC. ( 2014). Transforming Bangladesh's Garment Sector. International Finance Corporation.

60. ILO. (2004). Sexual Harassment at the Workplace in Nepal. Retrieved from https://www.ilo.org/wcmsp5/groups/public/@asia/@robangkok/@ilokathmandu/documents/publication/wcms_113780.pdf

61. ILO. (2017). Remediation financing in Bangladesh's ready made garment sector. Retrieved from CPD - RMG Project Office, Dhaka, Bangladesh: http://rmg-study.cpd.org.bd/remediation-financingbangladeshs-ready-made-garment-sector/

62. ILO. (2019). Inclusive Labour Markets, Labour Relations and Working Conditions Branch (INWORK). Retrieved from

63. Irene, P. K. (2014). Made in Lesotho: Examining variation in workers' perceptions of compliance with labour standards in Lesotho's clothing industry (D. B. Lipsky Ed. Vol. 3579143). Ann Arbor: Cornell University. 
64. Islam, M. M., Conigrave, K., Conigrave, K. M., \& Islam, M. M. (2008). HIV and sexual risk behaviors among recognized high-risk groups in Bangladesh: need for a comprehensive prevention program.

65. Islam, M. M., \& Conigrave, K. M. (2008). Review: HIV and sexual risk behaviors among recognized high-risk groups in Bangladesh: need for a comprehensive prevention program. International Journal of Infectious Diseases, 12, 363-370. doi:10.1016/j.ijid.2007.12.002

66. Islam, M. M., Conigrave, K. M., Miah, M. S., \& Kalam, K. A. (2010). HIV Awareness of Outgoing Female Migrant Workers of Bangladesh: A Pilot Study. Journal of Immigrant and Minority Health, 12(6), 940-946. doi:http://dx.doi.org/10.1007/s10903-0109329-5

67. Islam, M. R. (2013). Workers' Attitudes toward the Sustainable Human Resource Development in the Readymade Garments Industry of Bangladesh: An Empirical Analysis. Global Journal of Management and Business Studies, 3(9), 991-998.

68. Islam, M. S., Rakib, M. A., \& Adnan, A. (2016). Ready-made garments sector of Bangladesh: Its contribution and challenges towards development. Stud, 5(2).

69. Islam, T. (1998). LABOUR-BANGLADESH: Women Suffer Most in Garment Sweatshops. IPS. Retrieved from http://www.ipsnews.net/1998/12/labour-bangladesh-women-suffermost-in-garment-sweatshops/

70. Jahan, M. (2012). Women workers in Bangladesh garments industry: a study of the work environment. Int J Soc Sci Tomorrow, 1.

71. Kabeer, N., \& Mahmud, S. (2004a). Globalization, gender and poverty: Bangladeshi women workers in export and local markets. Journal of International Development, 16(1), 93-109.

72. Kabeer, N., \& Mahmud, S. (2004b). Rags, riches and women workers: export-oriented garment manufacturing in Bangladesh. Chains of fortune: Linking women producers and workers with global markets, 133-164.

73. Kabeer\&Mahmud. (2004). Rags, Riches and Women Workers: Export-oriented Garment Manufacturing in Bangladesh. Commonwealth Secretariat., 33-164.

74. Kabir, H., Maple, M., \& Fatema, S. R. (2018). Vulnerabilities of Women Workers in the Readymade Garment Sector of Bangladesh: A Case Study of Rana Plaza. Journal of International Women's Studies, 19(6), 224-235. 
75. Kabir, H., Maple, M., Usher, K., \& Islam, M. S. (2019). Health vulnerabilities of readymade garment (RMG) workers: a systematic review. BMC Public Health, 19(1), 70.

76. Karim, A., Shah, S. A. A., \& Salleh, R. (2014). Mobile Botnet Attacks: A Thematic Taxonomy, Cham.

77. Kernaghan, C. (2012). Criminal Negligence Leads to Tragedy at the Tazreen Fashions Factory in Bangladesh. Institute of Global Labour and Human Rights. Pittsburgh: Institute of Global Labour and Human Rights (IGLHR). Retrieved March, 28, 2015.

78. Khan, M. R. I., \& Wichterich, C. (2015). Safety and labour conditions: the accord and the national tripartite plan of action for the garment industry of Bangladesh.

79. Khan, S. (2001). Gender issues and the ready-made garment industry of Bangladesh. Globalisation and gender: changing patterns of employment in Bangladesh.

80. Khan, S. (2001). Gender Issues and the Ready-made Garments Industry of Bangladesh: the Trade Union Context. University Press Limited,

81. Khatun, T., Alamin, A., Saleh, F., Hossain, M., Hoque, A., \& Ali, L. (2013). Anemia among garment factory workers in Bangladesh. Middle-East Journal of Scientific Research, 16(4), 502-507.

82. Khosla, N. (2009). The ready-made garments industry in Bangladesh: A means to reducing gender-based social exclusion of women? Journal of International Women's Studies, 11(1), 289-303.

83. Kreps, D. M. (1997). Intrinsic motivation and extrinsic incentives. The American economic review, 87(2), 359-364.

84. Leedy, P., \& Ormrod, J. (2001). Practical Research: Planning and Design, Merrill Prentice Hall. New Jersey.

85. Lin, W.-Q., Wu, J., Yuan, L.-X., Zhang, S.-C., Jing, M.-J., Zhang, H.-S., . . . Wang, P.-X. (2015). Workplace violence and job performance among community healthcare Workers in China: the mediator role of quality of life. International Journal of Environmental Research and Public Health, 12(11), 14872-14886.

86. Magendans, A. E. (2014). The Accord on Fire and Building Safety in Bangladesh: True Commitment or Risk Management? , Asian Institute of Technology,

87. Mahmood, S. (2001). Education; Women in Bangladesh at Increasing Risk for HIV Infection. Women's Health Weekly, 12-13. .

88. Mahmood, S. (2004). The Socio-Economic Impact of HIV/AIDS in Bangladesh: The Role of Public Administration in Response to HIV/AIDS. Southern Business Review, 30(1), 25-32. 
89. Mahmood, S. (2005). Separation of power in Bangladesh: the role of public administration. Public Administration and Management, 10(4), 325-348.

90. Mahmood, S. (2006). Dengue: An Epidemic Is Largely a Failure in Public Health Administration! The Role of Dhaka City Corporation, DCC of Bangladesh. WORLD HEALTH \& POPULATION. doi:00.doi:10.12927/whp.2005.17900

91. Mahmood, S. (2007). HIV/AIDS in Bangladesh: The role of government in health and human services administration. Journal of Health and Human Services Administration(2), 129.

92. Mahmood, S. (2010). TB and HIV/AIDS in Bangladesh. Journal of AIDS and HIV Research, 2(4), 66-78.

93. Mahmood, S. (2012). Health systems in Bangladesh. Health Systems and Policy Research, 1(1), 1-4.

94. Mahmood, S. (2019). FEMALE GARMENT WORKERS'UNDERSTANDINGS OF HIV/AIDS IN $B A N G L A D E S H$. Paper presented at the AMER SOC TROP MED \& HYGIENE 8000 WESTPARK DR, STE 130, MCLEAN, VA 22101 USA, National Harbor, MD USA

95. Mahmood, S. (2020). Female Garment Workers' in Bangladesh: Violence, Gender and HIV/AIDS Journal of Social and Political Sciences, Vol.3 (No.2), 550-563.

doi:DOI: 10.31014/aior.1991.03.02.190

96. Mahmud, M. S., \& Rajath, V. (2017). Safety issues of female workers of garment industry in Gazipur District, Bangladesh. Journal of Applied and Advanced Research, 2(4), 265-269.

97. Mahmud, M. S., Rajath, V., Mahmud, R., Jahan, M. N., Hasan, M., \& Rahman, K. (2017). Prevalence of health hazards: A study on the female workers of garment industry in Gazipur District, Bangladesh. Journal of Applied and Advanced Research, 2(3), 184-188.

98. Mahmud, S. (2010). Why do garment workers in Bangladesh fail to mobilize? In In L Thompson \& C Tapscott (eds) Citizenship and Social Movements: Perspectives from the Global South. London: Zed, 10.

99. Majumder, P., \& Zohir, S. (1995). Empowering Women: Wage Employment in the Garments Industry. Journal of Women for Women.

100. Mirdha, R. U. (2015). Minister vows to set up bank for garment sector Daily Star. Retrieved from

https://www.thedailystar.net/business/minister-vows-set-bankgarment-sector-123871 
101. Mohd Hajaraih, S. K., Gordon, S. P., \& Tabb, K. M. (2019). Health outcomes among garment workers in low-middle income countries: a scoping review. Women's Health Bulletin, 6(3), 1-9.

102. Mondal, N. I., Hossain, M., \& Rahman, M. (2008). Knowledge and awareness about HIV/AIDS among garments workers in Gazipur District Bangladesh. Soc Sci, 3.

103. Mondal, N. I., Islam, M. R., Rahman, O., Rahman, S., \& Hoque, N. (2012). Determinants of HIV/AIDS awareness among garments workers in Dhaka City, Bangladesh. World J AIDS, 2. doi: 10.4236/wja.2012.24042

104. Morshed, M. M. (2007). A study on labor rights implementation in readymade garments (RMG) industry in Bangladesh: Bridging the gap between theory and practice, 2007. University of Wollongong, University theses collection.

105. Mottaleb, K. A., \& Sonobe, T. (2011). An inquiry into the rapid growth of the garment industry in Bangladesh. Economic Development and Cultural Change, 60(1), 67-89.

106. Muhammad, A. (2011). Wealth and deprivation: Ready-made garments industry in Bangladesh. Economic and Political weekly, 23-27.

107. Muhammad, N. U. (2012). A Study on The Work place Environment in Garment Industry: Challenges and Opportunities. (MSS course No.04: Thesis), University of Dhaka, Dhaka. (Ha3525)

108. NASP. (2004). National HIV Serological Surveillance, Bangladesh: Sixth Round Technical Report. Dhaka: Government of People's Republic of Bangladesh.

109. Naved, R., Mamun, M. A., Mourin, S. A., \& Parvin, K. (2018). A cluster randomized controlled trial to assess the impact of SAFE on spousal violence against women and girls in slums of Dhaka, Bangladesh. PLoS ONE [Electronic Resource], 13(6), 1-17. doi:10.1371/journal.pone.0198926

110. Naved, R., Rahman, T., Willan, S., Jewkes, R., \& Gibbs, A. (2018). Female garment workers' experiences of violence in their homes and workplaces in Bangladesh: A qualitative study. Social Science \& Medicine (1982), 196, 150-157. doi:10.1016/j.socscimed.2017.11.040

111. Nidhi, K. (2009). HIV/AIDS Interventions in Bangladesh: What Can Application of a Social Exclusion Framework Tell Us? Journal of Health, Population and Nutrition(4), 587.

112. O'Sullivan, L. F., \& Brooks-Gunn, J. (2005). The timing of changes in girls' sexual cognitions and behaviors in early 
adolescence: a prospective, cohort study. Journal of Adolescent Health, 37(3), 211-219. doi:10.1016/j.jadohealth.2004.08.019

113. Parvin, K., Al Mamun, M., Gibbs, A., Jewkes, R., \& Naved, R. T. (2018). The pathways between female garment workers' experience of violence and development of depressive symptoms. PLoS ONE [Electronic Resource], 13(11), e0207485.

114. Paul-Majumder, P. (1996). Health impact of women's wage employment: a case study of the garment industry of Bangladesh. The Bangladesh Development Studies, 59-102.

115. Paul-Majumder, P. (1997). Upward occupational mobility among female workers in the garment industry of Bangladesh.

116. Paul-Majumder, P., \& Begum, A. (2000). The gender imbalances in the export oriented garment industry in Bangladesh: World Bank, Development Research Group/Poverty Reduction and Economic ....

117. Perman, S., \& David, N. (2004). Behind the brand names: Working conditions and labour rights in export processing zones: International confederation of free trade unions.

118. Piot, P. (1995, Dec. 6-10,1995). AIDS-law and humanity. Paper presented at the AIDS- Law and Humanity, New Delhi, India.

119. Population Council. (2018). Key Population are at risk of HIV. http://www.popcouncil.org/research/key-populations-at-risk-forhiv.

120. Prentice, R., \& De Neve, G. (2017). Unmaking the global sweatshop: health and safety of the world's garment workers: University of Pennsylvania Press.

121. Rahman, M. M. (2008). The foreign trade of Bangladesh: Its composition, performance, trend, and policy. Journal of Bangladesh Studies, 9(2), 26-37.

122. Revolution, F. (2019). Women Garment Workers in Bangladesh Face Gender-Based Retaliation.

123. Rianon, N., Selwyn, B., Shahidullah, M., Swint, J. M., Franzini, L., \& Rasu, R. (2009). Cost of health education to increase STD awareness in female garment workers in Bangladesh. International Electronic Journal of Health Education, 12, 134-149.

124. Sato, H. (2014). Cournot competition and reduction of corruption to prevent garment factory fires in bangladesh.

125. Sayem, A. (2010). An assessment of risk behaviours to HIV/AIDS vulnerability among young female garment workers in Bangladesh.[Erratum appears in Int $\mathbf{J}$ STD AIDS. 2010 Mar;21(3):227 Note: Popsci, M [removed]]. International Journal 
of STD \& $\quad$ AIDS, 21(2), 133-137.

doi:https://dx.doi.org/10.1258/ijsa.2008.008455

126. Schwandt, T. A. (2005). A diagnostic reading of scientifically based research for education. Educational Theory, 55(3), 285-305.

127. Sharful Islam, K., \& Faisel, A. J. (1997). Sexuality nd Sexual Behaviours of Male STD Patients in Dhaka City. Paper presented at the ASCON VI Sixth Annual Scientific Conference Dhaka, Banglasdesh.

128. Sharmin, S., MohdIsa, M., \& Manan, W. A. (2014). The awareness levels on HIV/AIDS among garment women workers in Bangladesh. IOSR Journal of Humanities and Social Science, 19(5), 75-78. doi:10.9790/0837-19527578

129. Siddiqi, D. M. (2003). The Sexual Harassment of Industrial Workers: Strategies for Intervention in the Workplace and Beyond. 26(Centre for Policy Dialogue).

130. Siddiqui, J., \& Uddin, S. (2016). Human rights disasters, corporate accountability and the state: Lessons learned from Rana Plaza. Accounting, Auditing \& Accountability Journal, 29(4), 679704.

131. Siddiqui, T., \& Farah, M. (2011). Facing the challenges of labour migration from Bangladesh. Policy paper(4).

132. Solinap, G., Wawrzynski, J., Chowdhury, N., Zaman, H., Abid, T., Hoque, T. A., . . . Abid, M. R. (2018). A disease burden analysis of garment factory workers in Bangladesh: proposal for annual health screening. International Health, 11(1), 42-51. doi:10.1093/inthealth/ihy064

133. Tamanna, A. (2019). The challenge of adolescent SRH services in Bangladesh. Daily Star. Retrieved from

https://www.thedailystar.net/health/news/the-challenge-adolescentsrh-services-bangladesh-1815982

134. The Korea Times. (2013, 03/25/2013 Mar 25). Impressive Bangladesh. The Korea Times. Retrieved from http://search.proquest.com.libraryproxy.griffith.edu.au/docview/19 89788822 ? accountid $=14543$

135. UNAIDS. (2019). HIV estimates. Retrieved from Geneva, Switzerland:

https://techniumscience.com/index.php/socialsciences/about/contac $\mathrm{t}$

136. UNICEF. (2010). HIV and AIDS in Bangladesh. https://www.unicef.org/bangladesh/HIV_AIDS_in_Bangladesh(1). pdf 
137. World Bank. (2008). Bangladesh - Poverty Assessment for Bangladesh : Creating Opportunities and Bridging the East-West Divide.

138. World Bank. (2017). In Bangladesh, Empowering and Employing Women in the Garments Sector. Retrieved from Dhaka, Bangladesh:

https://www.worldbank.org/en/news/feature/2017/02/07/inbangladesh-empowering-and-employing-women-in-the-garmentssector

139. Yaya, S., Bishwajit, G., Danhoundo, G., Shah, V., \& Ekholuenetale, M. (2016). Trends and determinants of HIV/AIDS knowledge among women in Bangladesh. BMC Public Health, 16, 9. doi:10.1186/s12889-016-3512-0

140. Yunus, M., \& Yamagata, T. (2012). The garment industry in Bangladesh, dynamics of the garment industry in low income countries report no. 6. Institute of Developing Economics, Japan External Trade Organization, Japan. 